ISSN 1112-9867

Available online at

http://www.jfas.info

\title{
EVALUATING DELAY FACTORS IN THE CONSTRUCTION AND OPERATION OF PORT OPERATIONAL AREAS (CASE STUDY: SHAHID RAJAEE PORT COMPLEX)
}

\author{
M. Shirowzhan*1, M. Shanaki ${ }^{2}$, M. H. Sebt ${ }^{3}$, H. Naghash Toosi ${ }^{4}$ \\ ${ }^{1}$ Amirkabir Univerity of Technology, Tehran, Iran \\ ${ }^{2}$ Payame Noor University, Qeshm, Iran \\ ${ }^{3}$ Department of Construction Engineering and Management, Amirkabir Univerity of \\ Technology, Iran \\ ${ }^{4}$ Department of Construction Engineering and Management, Amirkabir Univerity of \\ Technology, Iran
}

Published online: 15 June 2016

\begin{abstract}
A significant part of the annual budget of developing countries is allocated to civil projects and the construction industry. In Iran, between $30 \%$ and $40 \%$ of the total budget of the country is allocated to this industry. However, the implementation of these projects is often faced with several problems that cause delays and increase costs.

The main objective of this research is to identify, analyze, and prioritize factors effective in delays in the construction of port operational area and to offer suggestions for preventing or reducing these delays. The statistical population of the study consists of employers,investors, consultants and contractors involved in the construction of port operational areas in Iran.

Data were collected through a questionnaire and were then analyzed using structural equation modeling in VPLS software. Results showed the most effective factors of the delay in the construction of port operational areas to be inadequate monitoring(11\%), poor planning and time scheduling (19\%), improper allocation of resources (24\%), cash flows changes(28\%),
\end{abstract}

Author Correspondence, e-mail: shirowzhan@yahoo.com

doi: http://dx.doi.org/10.4314/jfas.8vi2s.33 
failure to fund the projects on time (16\%)and other factors (27\%). These results can assist companies and legal authorities involved in the construction of port operational areas in Iran in making the right decisions based on the importance and effectiveness of each delay factor.

Keywords: Delay Factors, Port Construction Projects, Project Management.

\section{INTRODUCTION}

The development of infrastructures has a pivotal role in the development of any country. Therefore, investing in the development of the transport industry is of utmost importance, as all countries with good economies have allocated a remarkable quota of their investments to this field [23]. The emergence of new phenomena,such as globalization of the economy and free trade, has made the growth rate of marine trade surpass that of the global economy over the past two decades, which is indicative of the crucial role of the transport industry in facilitating production and trade and its indisputable impact on international interactions. Due to the low costs of sea transport compared to other systems of transportation, ports are distinctively positioned as the entry and exit points of goods, and therefore accelerating the development of this system of transportation and attracting investors and building the market for it is vital. The timely conclusion of every project based on its predicted costs is the main criterion for the project's overall success. Failure of the different divisions involved in the project to conclude the project on time is evidently one of the major problems and obstacles against the construction and operation of operational areas. Delays in establishing necessary infrastructures in ports cause market loss as international and regional compatitors take over and attract revenues of warehousing, transit, transshipment and logistics in addition to any other side revenues, and so our national yields from the global market are reduced [26].

Shahid Rajaee Port Complex is located at $20 \mathrm{~km}$ from the west of Bandar Abbas in Southern Iran at the longitude of $56^{\circ} 4^{\prime} \mathrm{E}$ and the latitude of $27^{\circ} 7^{\prime} \mathrm{N}$ on the North-South corridor of Iran. As for its marine position, Shahid Rajaee Port Complex is located at the estuary of the Persian Gulf, at the head of Hormuz Strait and on the north side of Qeshm Island. Given its strategic position and the accessibility of rail road, this port has always attracted numerous investors and traders. With a current area of 2200 hectares and 2400 hectares for future development, this port is the most dynamic port in Iran with $60-80 \%$ of the country's 
operational tonnage. It is also one of the world's 50 busiest container ports [12]. A glance at the increasing growth of certain ports in the region shows us that these attempts are directed at increasing their operational capacity [28].

A few assumptions will therefore be considered in this study, which will then be either confirmed or rejected using the student's t-test. Finally, the five main factors contributing to delays in the construction of port operational areas will be presented according to the four groups involved in the projects and based on the relative importance index.

\section{REVIEW OF PREVIOUS STUDIES}

Delay in concluding projects is a common problem in project management. In general, delay refers to any kind of deviation from the agreed schedule as a result of both internal and external factors of the system, which often creates difficulties for the director (the employer) and the executor (the contractor) and eventually affects the operation and objectives of the project [23]. Other consequences of delay in concluding projects include, missing opportunitiesand objectives predicted in holistic plans, wasted managing energies and national resources and investments, affecting secondary plans, persistence of problems in the executing and operating of the plans, increase in costs and decreased profit for contractors, diminished national interests, etc.

\subsection{Studies on the causes and effects of delay}

Astudy conducted by Assef et al [6] on massive Saudi Arabian construction projects identified 56 main factors for delay and classified them into 9 main groups. Findings showed that the contractors, the employers and the engineering companies agreed with the delay factors rankings.

In their research on massive Saudi Arabian projects, Assef and Al-Hajji found that 45 out of 76 projects studied had delays in conclusion and only $30 \%$ of the construction projects ended on time with the schedules [15]. On average, $10 \%$ to $30 \%$ was added to the original schedule for concluding the projects. 
In a study conducted by Mezher on the construction industry in Lebanon, 64 factors of delay were identified in 10 main groups, and the three groups involved with the project agreed with the rankings[19] .

Al-Momani conducted aquantitative analysis of 130 construction projects in Jordan, including, administrative, commercial and residential buildings, academic institutions and health care clinics [4]. Results of this study show that the main factors of delay deeply affect the timely conclusion of the projects. Therefore,the stake holders of the construction industry direct their attention to these factors if they are to minimize the risks of contract conflicts.

In another study conducted in Saudi Arabia on three groups involved in the water and sewage department projects (the employer, the consultant and the contractor), Al-Khalil and Al-Ghafly examine delays from three points of view, that is, repeatability, extent and responsibility toward delays so as to prevent delays and manage them better [3]. Results show that delays are not related to the location of the operation -rather to the contractor's grade. The employers and consultants regard the contractor as the main authority responsible for delay.

In one study conducted in Vietnam, Luu identified 16 factorsfor delay [16].

In Taiwan, Yang studied factors of delay in several build-operate-transfer (BOT) contracts and determined the main factors of delay through statistical methods [29].

In India,Doloi et al first identified 45 factors of delay in concluding projects of the construction industry, and then the mechanism of their effects was determined [8].

In Australia,Orangi et al studied the factors of delay in a number of pipeline projects, carefully examined the underlying reasons for these delays and then discussed methods of managing pipe projects and risks particular to the construction industry[22].

In Hong Kong, Cahn and Kumaraswamy identified delay factors of the construction industry[7]. They emphasized that the timely transfer of the projects on the part of the employer with adequate funding and favorable quality is key to any project's success. Failures in the timely conclusion of the project in line with the proposed cost and quality plan is often caused by unpredictable, negative factors. Often, when there are delays in concluding a project, the project has to be speeded, which imposes additional costs on the employer. 
Williams investigated the available methods for analyzing the effects of delays in buying time for large scale projects and specified their deficiencies[27].

In Iran, Fallahnejad identified 43 factors of delay for gas pipeline projects as well as the country's future plans for increasing gas export to 1300 million cubic meters per day and extending pipelines from 30,000 kilometers to 70,000 kilometers and then anaylzed the 10 main factors [10].

In Nigeria, Mansfield et al [17] conducted a study in which they showed that operations can only improve if their contract phase is improved. They identified 16 main factors for delays and soaring costs, including, payment adjustments, financial issues, poor contract management,material shortages and the inaccurate approximation of time and cost as well as cost changes.

Again in Nigeria, Yusif and Odeynika showed that there were delays in more than 7 out of 10 projects studied [21]. They divided the reasons for delay into two categories,partners of the project and external factors. Delays pertaining to the employer include, changes in order and demand, delayed decision-making and interrupted cash flow. Delays pertaining to the contractor include, financial problems, material management issues, planning and time management issues and shortage of human resources. Delays pertaining to the external factors include, unfavorable climates, natural disasters, strikes and labour conflicts.

In Malaysia,Sambasivian and Soon investigated the causes of delays in their country's construction industry and identified 10 main factors, including, in the order from most important to least,poor contractor planning, poor contractor site management,contractor being inexperienced, inadequate payments, difficulties with subcontractors, shortage of materials, human resources supply, shortage of equipment, poorly connected groups and problems of the construction phase. According to the researchers, the major consequences of delay were extended time, increased costs, conflicts, conflict resolution, litigation and ultimately the total resignation (transfer) of the project.

Table 1 demonstrates certain delay factors as per cited studies conducted in different countries. 
Table 1. Summary of previous studies on the causes of delay in construction projects

\begin{tabular}{cccc}
\hline Country & Year & Researchers & Major causes of delay \\
\hline Saudi & 1995 & Assaf et al [6] & 1. Slow preparation and approval of shop drawings \\
Arabia & & & 2. Delays in payments to contractors
\end{tabular}

3. Changes in design /design error

4. Shortages of labor supply

5. Poor workmanship

\begin{tabular}{|c|c|c|c|}
\hline \multirow[t]{3}{*}{ Labanon } & 1998 & $\begin{array}{l}\text { Mezher and } \\
\text { Tawil [19] }\end{array}$ & $\begin{array}{l}\text { 1. Owner had more concerns with regard to financial } \\
\text { issues }\end{array}$ \\
\hline & & & $\begin{array}{l}\text { 2. Contractors regarded contractual relationships the } \\
\text { most important }\end{array}$ \\
\hline & & & $\begin{array}{l}\text { 3. Consultant considered project management issue } \\
\text { to be the most Important causes of delay }\end{array}$ \\
\hline \multirow{3}{*}{$\begin{array}{l}\text { Saudi } \\
\text { Arabia }\end{array}$} & 1999 & Al-Khalil and & 1. Cash flow problems/financial difficulties \\
\hline & & Al-Ghafly [3] & 2. Difficulties in obtaining permits \\
\hline & & & 3. Lowest bid wins system \\
\hline \multirow[t]{5}{*}{ Jordan } & 2000 & Al-Moumani & 1. Poor design \\
\hline & & {$[4]$} & 2. Changes in order/design \\
\hline & & & 3. Weather \\
\hline & & & 4. Unforeseen site conditions \\
\hline & & & 5. Late deliveries \\
\hline Kuwait & 2005 & Koushki et al & 1. Changing order \\
\hline
\end{tabular}


[14]
2. Owners financial constraints

3. Owners lack of experience in the construction business

1. Slow preparation and approval of drawings Inadequate early planning of the project

2. Slowness of owner decision making

3. Shortage of manpower

4. Poor site management and supervision

5. Low productivity of manpower

\begin{tabular}{|c|c|c|c|}
\hline Saudi & 2005 & Assaf and & 1. Change in orders by the owner during construction \\
\hline \multirow[t]{4}{*}{ Arabia } & & Al-Hejji [5] & 2. Delay in progress payment \\
\hline & & & 3. Ineffective planning and scheduling \\
\hline & & & 4. Shortage of labor \\
\hline & & & $\begin{array}{l}\text { 5. Difficulties in financing on the part of the } \\
\text { contractor }\end{array}$ \\
\hline \multirow[t]{2}{*}{ Jordan } & 2007 & Sweis et al [26] & 1. Financial difficulties faced by the contractor \\
\hline & & & 2. Many change orders by the owner \\
\hline \multirow[t]{3}{*}{ Vietnam } & 2008 & Luu et al [16] & 1. Financial difficulties of owners and contractors \\
\hline & & & 2. Contractor's inadequate experience \\
\hline & & & 3. Shortage of materials \\
\hline Taiwan & 2009 & Yang et al [29] & 1. Improper contract planning \\
\hline
\end{tabular}


2. Debt problem

3. Uncertainly on political issues and government-finished items

India 2011 Doloi et al [8] 1. Lack of commitment

2. Inefficient site management

3. Poor site coordination

4. Improper planning

5. Lack of clarity in project scope

6. Lack of communication

7. Substandard contract
Australia 2011 Orangi et
1. Design changes
al[22]
2. Design errors
3. Poor communication
4. Sub-Surface investigation inadequacies
5. Weather condition
6. Procurement delays
7. Site management problems
8. Rework
9. Cultural and heritage management issues

Iran 2012 Fallahnejad 1. Imported materials 
2. Unrealistic project duration

3. Client -related materials

4. Land expropriation

5. Change orders

6. Contractor selection methods

7. Payment to contractor

8. Obtaining permits

9. Suppliers

10. Contractors' cash flow

There are significant consequences and damages caused by delays in the constructing and operat in go port operational areas in Iran, including, increased overhead expenses, increased costs directly related to inflation, disrupted beneficiary profits, loss of market due to lagging behind competitors and new technologies, failing to meet the employer's demands and project objectives, losing technological and economic feasibility of the project, etc. [22]. In other words, the untimely conclusion of projects imposes huge costs on all partners. Identifying delay factors is therefore essential for their proper analysis and for finding solutions that help prevent from the factors that are more significant and common.

\subsection{Research hypotheses and conceptual framework}

The questionnaire contained 6 main factors of delay as identified through interviews with experts and partners of the port operational area construction projects based on 6 assumptions:

1. Inadequate monitoring affects delays in the construction and operation of port operational areas.

2. Poor planning and time scheduling affects delays in the construction and operation of port operational areas. 
3. Improper allocation of resources affects delays in the construction and operation of port operational areas.

4. Cash flow changes affects delays in the construction and operation of port operational areas.

5. Failure to fund the project son time affects delays in the construction and operation of port operational areas.

6. Other factors also affect delays in the construction and operation of port operational areas.

In order to identify the more effective factors (items of the questionnaire and the indexes) and provide a pattern (given the specified indexes), the factor analysis and the Partial Least Square (PLS) methods were used. The PL Sapproximation method is a revised version of the regression and the factor analysis methods that determines the coefficients in a way that the yielded model is at its maximum capacity for providing explanations and interpretations and is able to predict the final dependent variable with maximum accuracy. Figure 1 shows the conceptual model of the graphical chart yielded by VPLS.

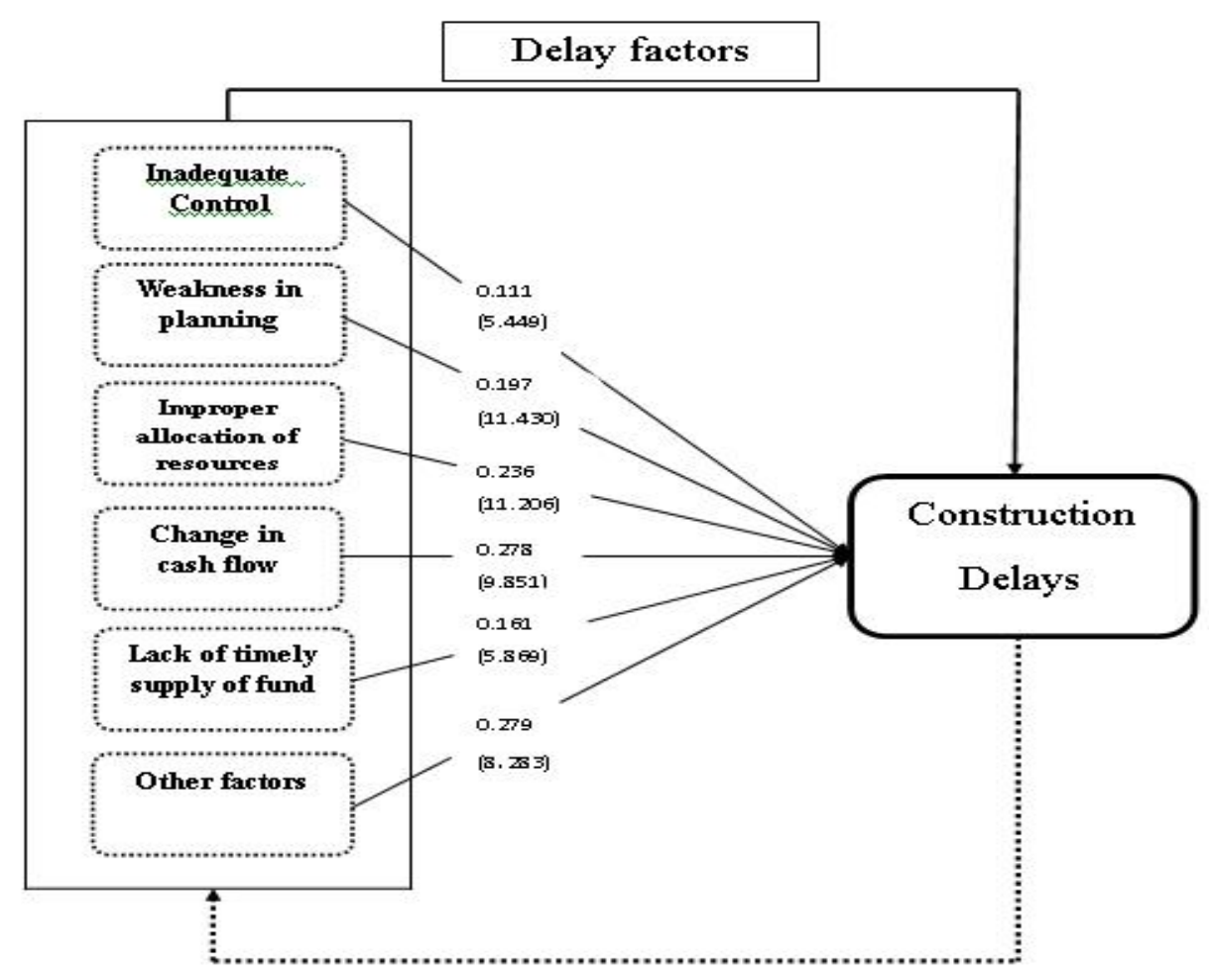

Fig.1. Conceptual model of the research 


\section{RESEARCH METHODOLOGY}

This section presents the research hypotheses and the conceptual framework regarding the Evaluating Delay Factorsin the Constructionand Operation of Port Operational Areas followed by the methodological and statistical approaches applied in this study.

\subsection{Data collection method}

This research is a descriptive survey based on its methodology and goals and its data collecting technique. It examines 30 port operational areas subject to delays. Project partners include, the employer, investors, consultants and contractors. A total of 120 questionnaires were developed and then distributed among the project partners. Sampling was conducted in 2015. Sample size was determined through a national census. Table 2 presents the number of questionnaires distributed and the ones returned.

Table 2. Number of questionnaires distributed and returned

\begin{tabular}{llllll}
\hline & Employer & Investor & Consultant & Contractor & Total \\
\hline $\begin{array}{l}\text { Distributed } \\
\text { questionnaires }\end{array}$ & 30 & 30 & 30 & 30 & 120 \\
& & & & & \\
Returned & 25 & 20 & 20 & 18 & 83 \\
questionnaires & & & & & \\
\hline
\end{tabular}

The factors of delay were classified into 6 groups with 30 items and using a five-point Likert scale $($ very much $=5$, a lot $=4$, medium $=3$, little $=2$, very little $=1$ ):

1. Inadequate monitoring: Failure to use efficient methods for operating and monitoring projects; poor notifying on the part of the monitoring group; the degree of monitoring and guiding the contractors.

2. Poor planning and time scheduling: Delay in decision making; poor planning and time scheduling; delay in project approval and notification; delay in delivery of land; continuous changes to the plan.

3. Improper allocation of resources: Shortage of specialist human resources for implementing the project; delay in the delivery of material and equipment; shortage 
of resources and facilities for performing the activities; failing to provide resources on-time; poor coordination between staff and operational personnel; shortage of construction material sources.

4. Cash flow changes: Difficulties in making monthly payments; contractor's financial problems; delayed prepayments to the contractor; delay in invoice approval and payment, poor approximation of costs; increased material and equipment costs.

5. Failure to fund the projects on time: Investor's reduced financial capacity for providing the right cash flow; delay in providing cash flow and payment to personnel and subcontractors; changes to the banking system and loan policies.

6. Other factors: Ignoring extenuating circumstances (such as political and strategic conditions); weather conditions of the region; excessive changes to the top management; delay in releasing lands and solving conflicts; existence of multiple rules and decision makers; contract conflicts between the employer and the investor; disadvantageous bureaucracies.

An initial sample of 20 was first used to determine the questionnaire validity. The questionnaire reliability was then assessed using Cronbach's alpha test. The questionnaire contained 30 items with a total Cronbach's alpha of 93\%. As the Cronbach's alpha is higher than $70 \%$, the questionnaire reliability is confirmed. The validity of the data collection tool is presented in table 5, indicating relatively high validity.

As for data analysis, the Kolmogorov-Smirnov test was used to verify the normal distribution of the sample and its histogram was compared to the normal curve. The analysis of covariance was then used to compare delay factors according to the project partners (employers, investors, consultants and contractors). The relative importance index was then use to prioritize the identified factors of delay according to the project partners. The VPLS software was then used for modeling the structural equations for examining the effect of each identified delay factor on the construction and operation of the port operational areas and to also analyze the correlation between each of these factors.

\section{DATA ANALYSIS}

\section{4-1.Demographic data analysis}


All respondents were male, with $85.6 \%$ having a bachelor's degree or higher and the remaining $14.4 \%$ having lower than bachelor's degrees. A total of $74.7 \%$ of respondents had more than 7 years and $25.3 \%$ had less than 7 years of work experience. Lastly, $30.1 \%$ of respondents belonged to the category of employers, $24.1 \%$ were investors, $24.1 \%$ were consultants and $21.7 \%$ were contractors.

The Kolmogorov-Smirnov test was used to verify the normal distribution of the sample. As the Kolmogorov-Smirnov test's level of significance is equal to 0.23 and is thus higher than 0.05 , it can be concluded that the sample distribution has been normal at a $95 \%$ confidence level and that the analysis of variance parameters test can be used to compare delay factors according to the four project partners.

\section{4-2. Descriptive statistics}

Table 3 presents descriptive statistics yielded by the study based on the assumptions and the items, including the mean and the standard deviation according to the project partners as well as the total mean and the total standard deviation. The last column shows the Cronbach's alpha for the assumptions.

Table 3. Descriptive statistics of examined variables

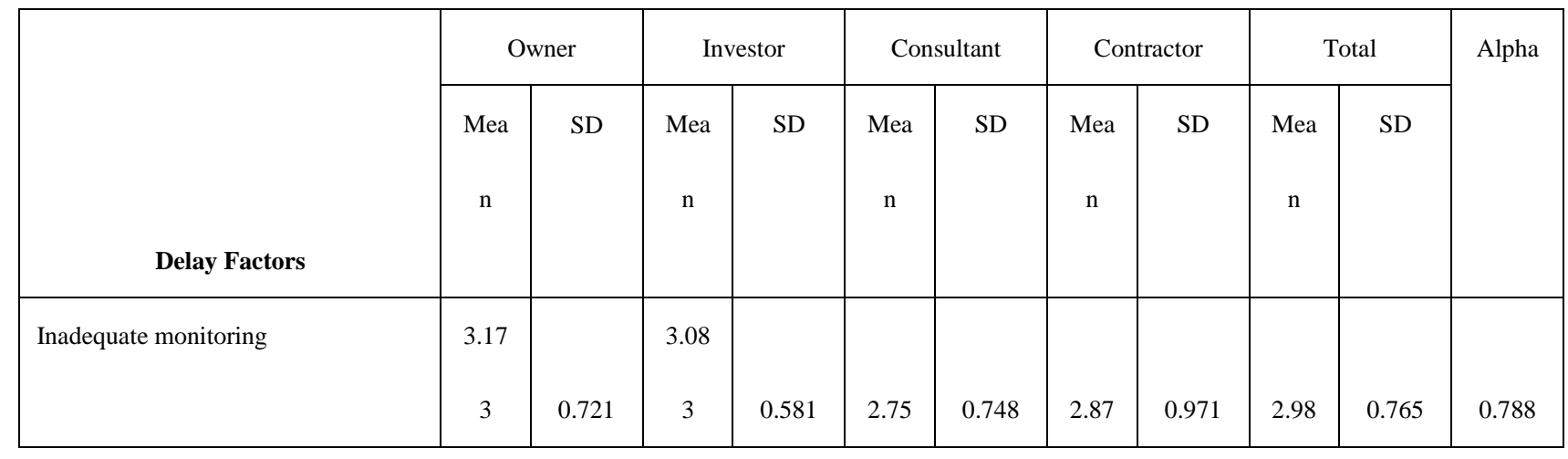




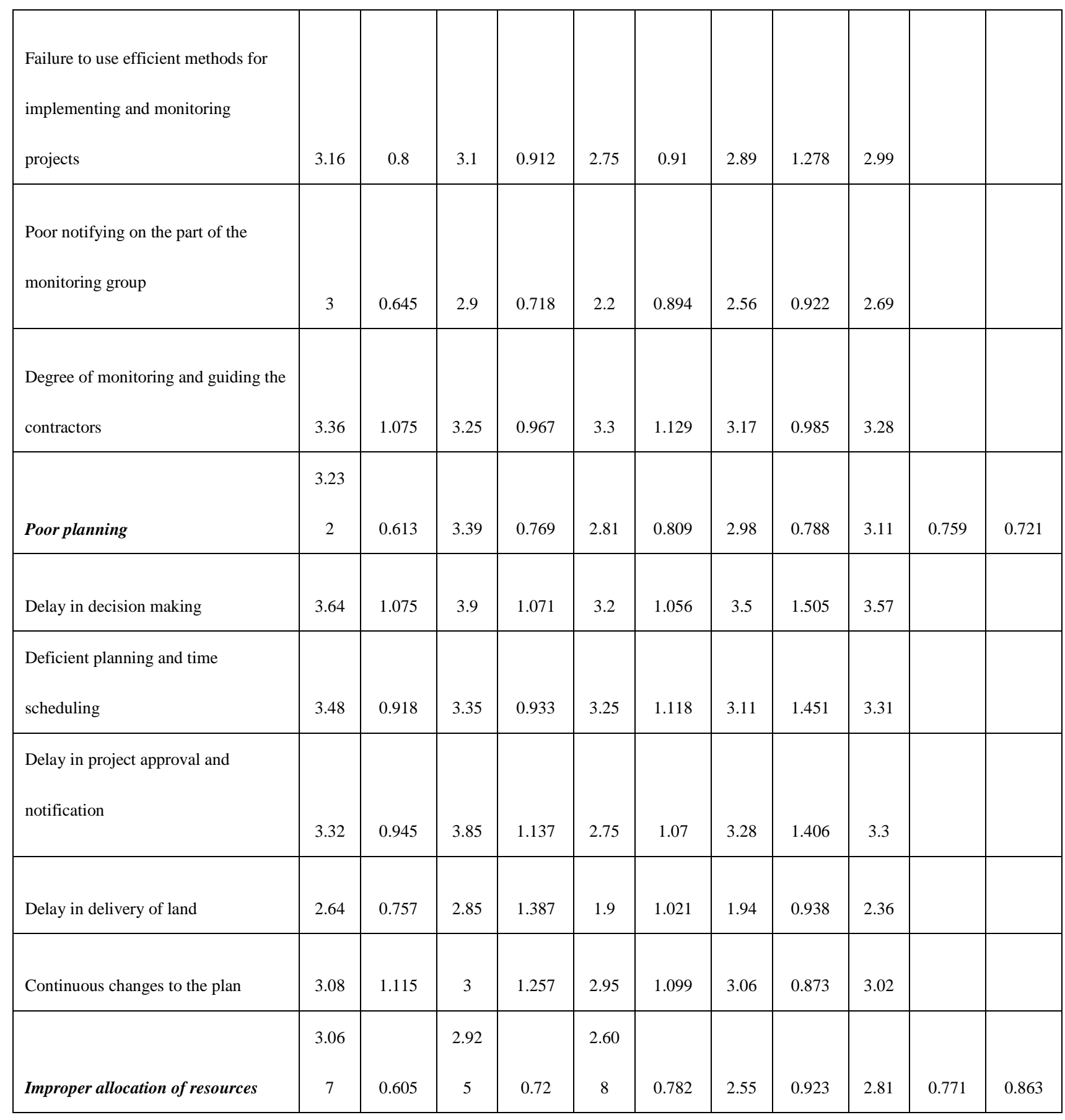




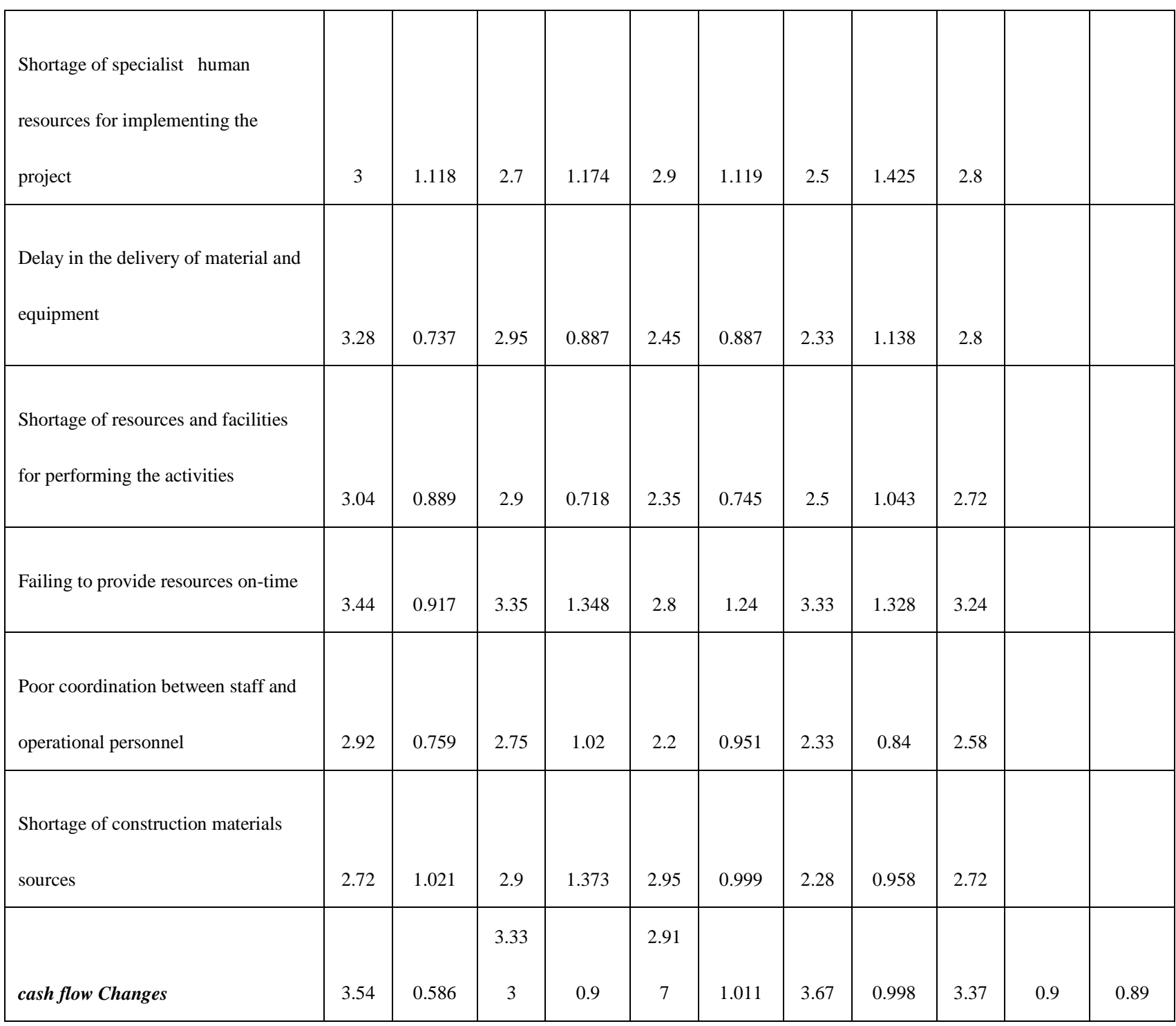




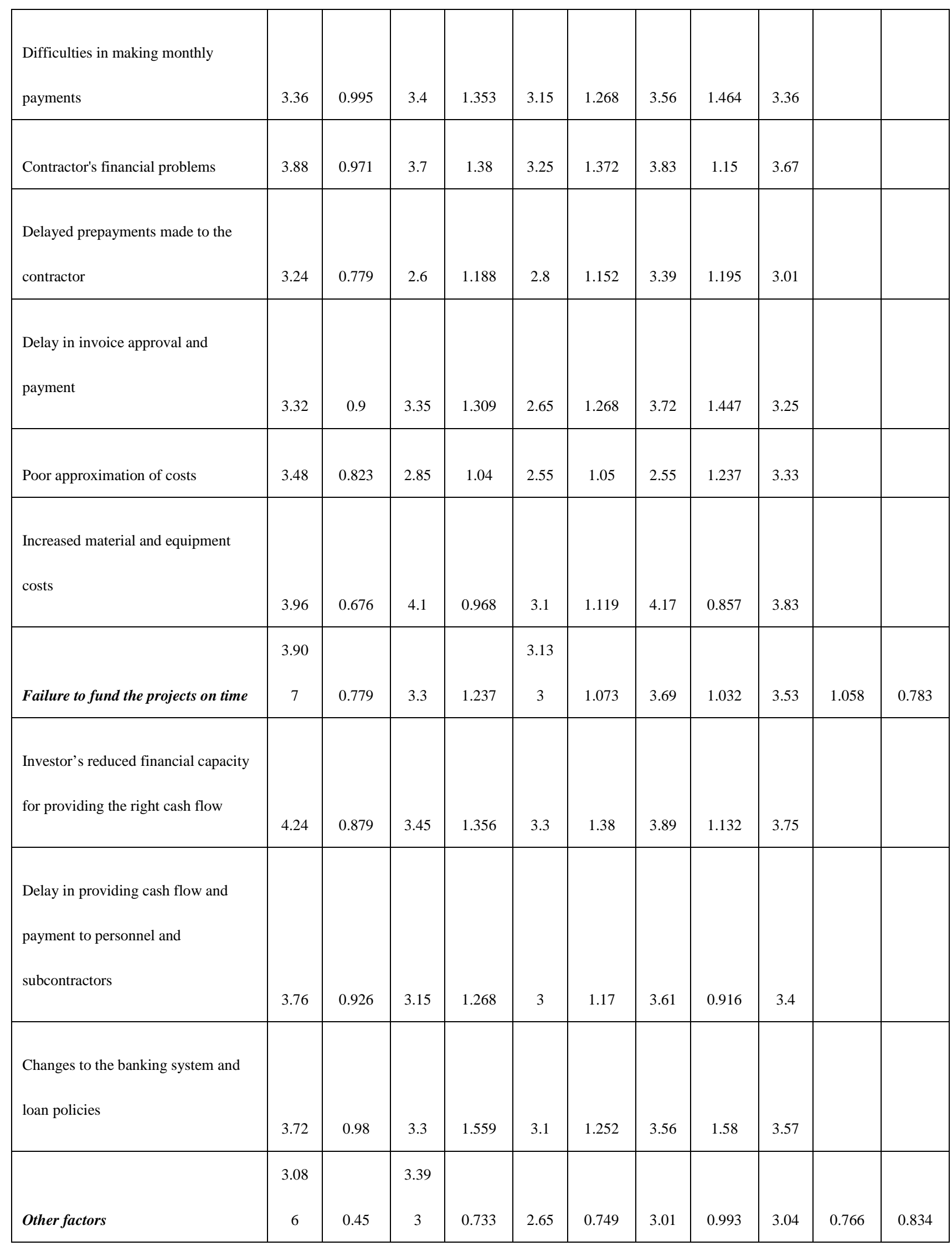




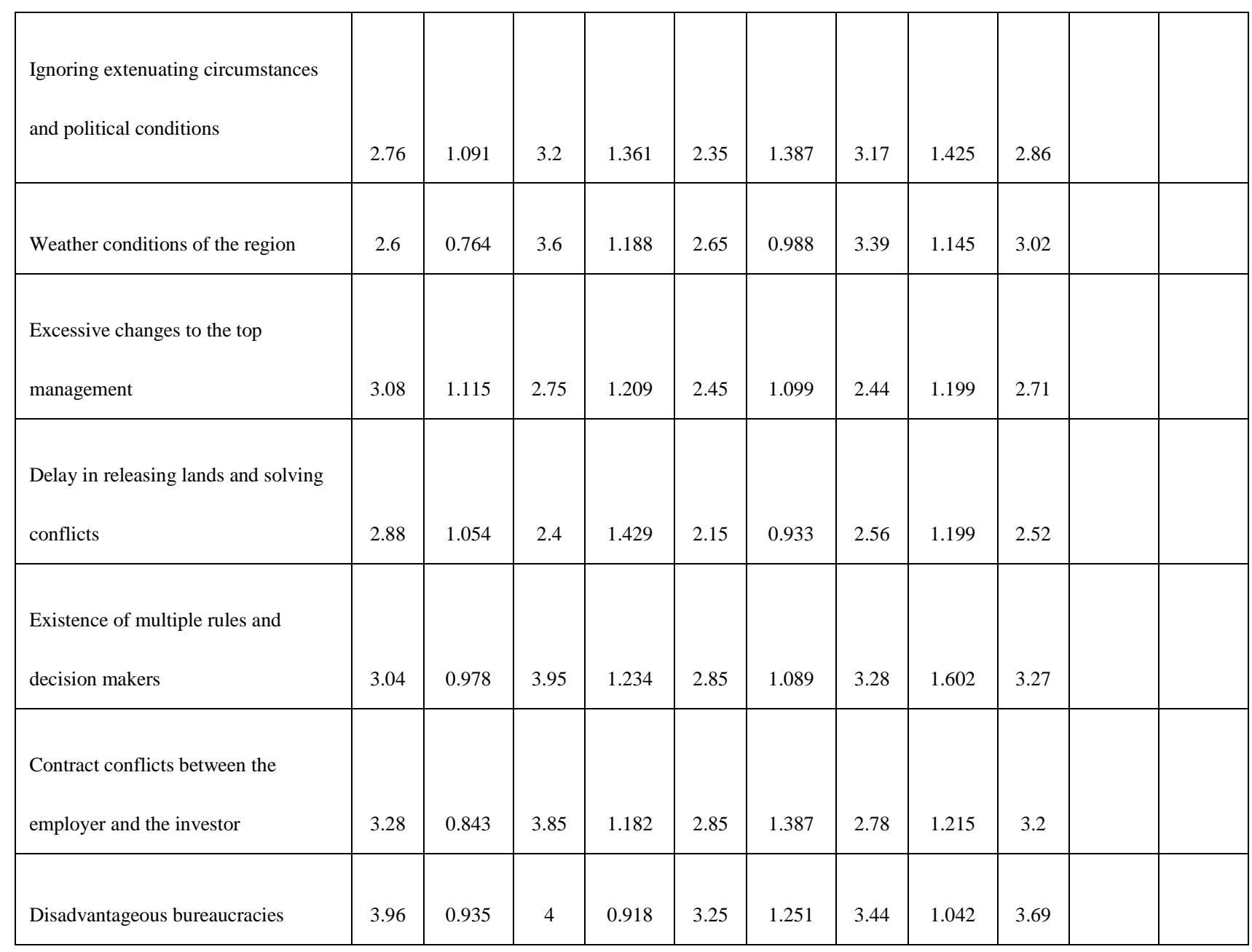

\section{4-3. Examination and comparison of delay factors according to the professions (Analysis}

\section{of Variance)}

Table 4 compares and examines each delay factor according to the employer, investor, consultant, and contractor's point of view.

Table 4. Comparison of Delay Factors According to the Professions Using the Analysis of Variance Test

\begin{tabular}{|l|c|c|c|}
\hline \multicolumn{1}{|c|}{ Delay Factors } & DF & F & Sig. \\
\hline Inadequate monitoring & 3 & 1.399 & .249 \\
\hline Poor planning and time scheduling & 3 & 2.469 & .068 \\
\hline Improper allocation of resources & 3 & 2.340 & .080 \\
\hline Cash flow changes & 3 & 2.828 & .044 \\
\hline Failure to fund the projects ontime & 3 & 2.577 & .060 \\
\hline Other factors & 3 & 3.473 & .020 \\
\hline
\end{tabular}


Table 4 shows that the inadequate monitoring factor with a significance level of 0.249 , which is above 0.10 , is not significantly different according to either professions at a confidence level of 0.90 . Other factors have a significance level lower than 0.10 and are therefore significantly different according to all professions at a confidence level of 0.90 .

\section{4-4. Ranking the Relative Importance of Delay Factors}

Based on the relative importance index, we rank all the delay factors in table 5. The relative importance index is defined as:

RII: Relative Importance Index;

$\mathrm{W}$ : The weight assigned to each item according to the respondent (on a scale from 1 to 5);

$$
R I I=\frac{\sum W}{A * N}
$$

A: Maximum weight (in this case,5);

$\mathrm{N}$ : Total number of respondents

Table 5. Ranking of the study's assumptions based on the relative importance index

\begin{tabular}{|c|c|c|c|c|c|c|c|c|c|c|}
\hline \multirow[t]{2}{*}{ Title } & \multicolumn{2}{|c|}{ Employer } & \multicolumn{2}{|c|}{ Investor } & \multicolumn{2}{|c|}{ Consultant } & \multicolumn{2}{|c|}{ Contractor } & \multicolumn{2}{|c|}{ General } \\
\hline & RII & $\begin{array}{l}\text { Ranki } \\
\text { ng }\end{array}$ & RII & $\begin{array}{c}\text { Ranki } \\
\text { ng }\end{array}$ & RII & $\begin{array}{c}\text { Ranki } \\
\text { ng }\end{array}$ & RII & $\begin{array}{c}\text { Ranki } \\
\text { ng }\end{array}$ & RII & $\begin{array}{c}\text { Ranki } \\
\text { ng }\end{array}$ \\
\hline Inadequate & 0.63 & 4 & 0.61 & 5 & 0.55 & 4 & 0.57 & 5 & 0.59 & 5 \\
\hline monitoring & 5 & & 6 & & & & 4 & & 6 & \\
\hline $\begin{array}{l}\text { Poor planning and } \\
\text { time scheduling }\end{array}$ & $\begin{array}{c}0.64 \\
6\end{array}$ & 3 & $\begin{array}{c}0.67 \\
8\end{array}$ & 2 & $\begin{array}{c}0.56 \\
2\end{array}$ & 3 & $\begin{array}{c}0.59 \\
5\end{array}$ & 4 & $\begin{array}{c}0.62 \\
3\end{array}$ & 3 \\
\hline $\begin{array}{l}\text { Improper allocation of } \\
\text { resources }\end{array}$ & $\begin{array}{c}0.61 \\
3\end{array}$ & 6 & $\begin{array}{c}0.58 \\
5\end{array}$ & 6 & $\begin{array}{c}0.52 \\
1\end{array}$ & 6 & $\begin{array}{c}0.50 \\
9\end{array}$ & 6 & $\begin{array}{c}0.56 \\
2\end{array}$ & 6 \\
\hline Cash flow changes & $\begin{array}{c}0.70 \\
8\end{array}$ & 2 & $\begin{array}{c}0.66 \\
7\end{array}$ & 3 & $\begin{array}{c}0.58 \\
3\end{array}$ & 2 & $\begin{array}{c}0.73 \\
3\end{array}$ & 2 & $\begin{array}{c}0.67 \\
3\end{array}$ & 2 \\
\hline $\begin{array}{l}\text { Failing to provide } \\
\text { resources on-time }\end{array}$ & $\begin{array}{c}0.78 \\
1\end{array}$ & 1 & 0.66 & 4 & $\begin{array}{c}0.62 \\
6\end{array}$ & 1 & $\begin{array}{c}0.73 \\
7\end{array}$ & 1 & $\begin{array}{c}0.70 \\
5\end{array}$ & 1 \\
\hline Other factors & $\begin{array}{c}0.61 \\
7\end{array}$ & 5 & $\begin{array}{c}0.67 \\
8\end{array}$ & 1 & 0.53 & 5 & $\begin{array}{c}0.60 \\
1\end{array}$ & 3 & $\begin{array}{c}0.60 \\
7\end{array}$ & 4 \\
\hline
\end{tabular}


Table 6. Descriptive statistics of the research variables

\begin{tabular}{|c|c|c|c|c|c|c|c|c|c|c|}
\hline \multirow{2}{*}{$\begin{array}{l}\text { Relative Importance } \\
\text { Index }\end{array}$} & \multicolumn{2}{|c|}{ Employer } & \multicolumn{2}{|c|}{ Investor } & \multicolumn{2}{|c|}{ Consultant } & \multicolumn{2}{|c|}{ Contractor } & \multirow{2}{*}{$\begin{array}{l}\text { Total } \\
\text { Ranki } \\
\text { ng }\end{array}$} & \multirow{2}{*}{$\begin{array}{c}\text { Tota } \\
1 \\
\text { RII }\end{array}$} \\
\hline & RII & $\begin{array}{c}\text { Ranki } \\
\text { ng }\end{array}$ & RII & $\begin{array}{c}\text { Ranki } \\
\text { ng }\end{array}$ & RII & $\begin{array}{c}\text { Ranki } \\
\text { ng }\end{array}$ & RII & $\begin{array}{c}\text { Ranki } \\
\text { ng }\end{array}$ & & \\
\hline $\begin{array}{l}\text { Failure to use efficient } \\
\text { methods for } \\
\text { implementing and } \\
\text { monitoring projects }\end{array}$ & $\begin{array}{c}0.6 \\
3\end{array}$ & 18 & $\begin{array}{c}0.6 \\
2\end{array}$ & 18 & $\begin{array}{c}0.5 \\
5\end{array}$ & 18 & $\begin{array}{c}0.5 \\
8\end{array}$ & 20 & 0.60 & 20 \\
\hline $\begin{array}{l}\text { Poor notifying on the } \\
\text { part of the monitoring } \\
\text { group }\end{array}$ & $\begin{array}{c}0.6 \\
0\end{array}$ & 23 & $\begin{array}{c}0.5 \\
8\end{array}$ & 18 & $\begin{array}{c}0.4 \\
4\end{array}$ & 27 & $\begin{array}{c}0.5 \\
1\end{array}$ & 22 & 0.54 & 27 \\
\hline $\begin{array}{l}\text { Degree of monitoring } \\
\text { and guiding the } \\
\text { contractors }\end{array}$ & $\begin{array}{c}0.6 \\
7\end{array}$ & 11 & $\begin{array}{c}0.6 \\
5\end{array}$ & 21 & $\begin{array}{c}0.6 \\
6\end{array}$ & 1 & $\begin{array}{c}0.6 \\
3\end{array}$ & 6 & 0.66 & 11 \\
\hline $\begin{array}{l}\text { Delay in decision } \\
\text { making }\end{array}$ & $\begin{array}{c}0.7 \\
3\end{array}$ & 7 & $\begin{array}{c}0.7 \\
8\end{array}$ & 15 & $\begin{array}{c}0.6 \\
4\end{array}$ & 6 & $\begin{array}{c}0.7 \\
0\end{array}$ & 8 & 0.71 & 5 \\
\hline $\begin{array}{l}\text { Deficient planning and } \\
\text { time scheduling }\end{array}$ & $\begin{array}{c}0.7 \\
0\end{array}$ & 8 & $\begin{array}{c}0.6 \\
7\end{array}$ & 4 & $\begin{array}{c}0.6 \\
5\end{array}$ & 3 & $\begin{array}{c}0.6 \\
2\end{array}$ & 18 & 0.66 & 9 \\
\hline $\begin{array}{l}\text { Delay in project } \\
\text { approval } \\
\text { and notification }\end{array}$ & $\begin{array}{c}0.6 \\
6\end{array}$ & 13 & $\begin{array}{c}0.7 \\
7\end{array}$ & 11 & $\begin{array}{c}0.5 \\
5\end{array}$ & 19 & $\begin{array}{c}0.6 \\
6\end{array}$ & 14 & 0.66 & 10 \\
\hline Delay in delivery of land & $\begin{array}{c}0.5 \\
3\end{array}$ & 29 & $\begin{array}{c}0.5 \\
7\end{array}$ & 5 & $\begin{array}{c}0.3 \\
8\end{array}$ & 30 & $\begin{array}{c}0.3 \\
9\end{array}$ & 30 & 0.47 & 30 \\
\hline $\begin{array}{l}\text { Continuous changes to } \\
\text { the plan }\end{array}$ & $\begin{array}{c}0.6 \\
2\end{array}$ & 19 & 0.6 & 24 & $\begin{array}{c}0.5 \\
9\end{array}$ & 11 & $\begin{array}{c}0.6 \\
1\end{array}$ & 19 & 0.60 & 17 \\
\hline $\begin{array}{l}\text { Shortage of specialist } \\
\text { human resources for }\end{array}$ & $\begin{array}{c}0.6 \\
0\end{array}$ & 24 & $\begin{array}{c}0.5 \\
4\end{array}$ & 19 & $\begin{array}{c}0.5 \\
8\end{array}$ & 13 & $\begin{array}{c}0.5 \\
0\end{array}$ & 24 & 0.56 & 22 \\
\hline
\end{tabular}




\begin{tabular}{|c|c|c|c|c|c|c|c|c|c|c|}
\hline \multicolumn{11}{|l|}{ operating the project } \\
\hline $\begin{array}{l}\text { Delay in the delivery of } \\
\text { material and equipment }\end{array}$ & $\begin{array}{c}0.6 \\
6\end{array}$ & 15 & $\begin{array}{c}0.5 \\
9\end{array}$ & 28 & $\begin{array}{c}0.4 \\
9\end{array}$ & 23 & $\begin{array}{c}0.4 \\
7\end{array}$ & 27 & 0.56 & 23 \\
\hline $\begin{array}{l}\text { Shortage of resources } \\
\text { and facilities for } \\
\text { performing the activities }\end{array}$ & $\begin{array}{c}0.6 \\
1\end{array}$ & 21 & $\begin{array}{c}0.5 \\
8\end{array}$ & 20 & $\begin{array}{c}0.4 \\
7\end{array}$ & 25 & $\begin{array}{c}0.5 \\
0\end{array}$ & 25 & 0.54 & 24 \\
\hline $\begin{array}{l}\text { Failing to provide } \\
\text { resources on-time }\end{array}$ & $\begin{array}{c}0.6 \\
9\end{array}$ & 10 & $\begin{array}{c}0.6 \\
7\end{array}$ & 22 & $\begin{array}{c}0.5 \\
6\end{array}$ & 16 & $\begin{array}{c}0.6 \\
7\end{array}$ & 12 & 0.65 & 14 \\
\hline $\begin{array}{l}\text { Poor coordination } \\
\text { between staff and } \\
\text { operational personnel }\end{array}$ & $\begin{array}{c}0.5 \\
8\end{array}$ & 25 & $\begin{array}{c}0.5 \\
5\end{array}$ & 12 & $\begin{array}{c}0.4 \\
4\end{array}$ & 28 & $\begin{array}{c}0.4 \\
7\end{array}$ & 28 & 0.52 & 28 \\
\hline $\begin{array}{l}\text { Shortage of loan } \\
\text { resources }\end{array}$ & $\begin{array}{c}0.5 \\
4\end{array}$ & 28 & $\begin{array}{c}0.5 \\
8\end{array}$ & 26 & $\begin{array}{c}0.5 \\
9\end{array}$ & 12 & $\begin{array}{c}0.4 \\
6\end{array}$ & 29 & 0.54 & 25 \\
\hline $\begin{array}{l}\text { Difficulties in making } \\
\text { monthly payments }\end{array}$ & $\begin{array}{c}0.6 \\
7\end{array}$ & 12 & $\begin{array}{c}0.6 \\
8\end{array}$ & 23 & $\begin{array}{c}0.6 \\
3\end{array}$ & 7 & $\begin{array}{c}0.7 \\
1\end{array}$ & 6 & 0.67 & 8 \\
\hline $\begin{array}{l}\text { Contractor's financial } \\
\text { problems }\end{array}$ & $\begin{array}{c}0.7 \\
8\end{array}$ & 4 & $\begin{array}{r}0.7 \\
4\end{array}$ & 10 & $\begin{array}{c}0.6 \\
5\end{array}$ & 4 & $\begin{array}{c}0.7 \\
7\end{array}$ & 3 & 0.73 & 4 \\
\hline $\begin{array}{l}\text { Delayed prepayments } \\
\text { made to the contractor }\end{array}$ & $\begin{array}{c}0.6 \\
5\end{array}$ & 17 & $\begin{array}{c}0.5 \\
2\end{array}$ & 7 & $\begin{array}{c}0.5 \\
6\end{array}$ & 17 & $\begin{array}{c}0.6 \\
8\end{array}$ & 10 & 0.60 & 19 \\
\hline $\begin{array}{l}\text { Delay in invoice } \\
\text { approval and payment }\end{array}$ & $\begin{array}{c}0.6 \\
6\end{array}$ & 14 & $\begin{array}{c}0.6 \\
7\end{array}$ & 29 & $\begin{array}{c}0.5 \\
3\end{array}$ & 20 & $\begin{array}{c}0.7 \\
4\end{array}$ & 4 & 0.65 & 13 \\
\hline $\begin{array}{l}\text { Poor approximation of } \\
\text { costs }\end{array}$ & $\begin{array}{c}0.7 \\
0\end{array}$ & 9 & $\begin{array}{c}0.5 \\
7\end{array}$ & 13 & $\begin{array}{c}0.5 \\
1\end{array}$ & 22 & $\begin{array}{c}0.6 \\
7\end{array}$ & 13 & 0.61 & 16 \\
\hline
\end{tabular}




\begin{tabular}{|c|c|c|c|c|c|c|c|c|c|c|}
\hline $\begin{array}{l}\text { Increased material and } \\
\text { equipment costs }\end{array}$ & $\begin{array}{c}0.7 \\
9\end{array}$ & 2 & $\begin{array}{c}0.8 \\
2\end{array}$ & 25 & $\begin{array}{c}0.6 \\
2\end{array}$ & 8 & $\begin{array}{c}0.8 \\
3\end{array}$ & 1 & 0.77 & 1 \\
\hline $\begin{array}{l}\text { Investor's reduced } \\
\text { financial capacity for } \\
\text { providing the right cash } \\
\text { flow }\end{array}$ & $\begin{array}{c}0.8 \\
5\end{array}$ & 1 & $\begin{array}{c}0.6 \\
9\end{array}$ & 1 & $\begin{array}{c}0.6 \\
6\end{array}$ & 2 & $\begin{array}{c}0.7 \\
8\end{array}$ & 2 & 0.75 & 2 \\
\hline $\begin{array}{l}\text { Delay in providing cash } \\
\text { flow and payment to } \\
\text { personnel and } \\
\text { subcontractors }\end{array}$ & $\begin{array}{c}0.7 \\
5\end{array}$ & 5 & $\begin{array}{c}0.6 \\
3\end{array}$ & 9 & 0.6 & 10 & $\begin{array}{c}0.7 \\
2\end{array}$ & 5 & 0.68 & 7 \\
\hline $\begin{array}{l}\text { Changes to the banking } \\
\text { system and loan policies }\end{array}$ & $\begin{array}{c}0.7 \\
4\end{array}$ & 6 & $\begin{array}{c}0.6 \\
6\end{array}$ & 17 & $\begin{array}{c}0.6 \\
2\end{array}$ & 9 & $\begin{array}{c}0.7 \\
1\end{array}$ & 7 & 0.69 & 6 \\
\hline $\begin{array}{l}\text { Ignoring extenuating } \\
\text { circumstances and } \\
\text { political conditions }\end{array}$ & $\begin{array}{c}0.5 \\
5\end{array}$ & 27 & $\begin{array}{c}0.6 \\
4\end{array}$ & 14 & $\begin{array}{c}0.4 \\
7\end{array}$ & 26 & $\begin{array}{c}0.6 \\
3\end{array}$ & 17 & 0.57 & 21 \\
\hline $\begin{array}{l}\text { Weather conditions of } \\
\text { the region }\end{array}$ & $\begin{array}{c}0.5 \\
2\end{array}$ & 30 & $\begin{array}{c}0.7 \\
2\end{array}$ & 16 & $\begin{array}{c}0.5 \\
3\end{array}$ & 21 & $\begin{array}{c}0.6 \\
8\end{array}$ & 11 & 0.60 & 18 \\
\hline $\begin{array}{l}\text { Excessive changes to the } \\
\text { top management }\end{array}$ & $\begin{array}{c}0.6 \\
2\end{array}$ & 20 & $\begin{array}{c}0.5 \\
5\end{array}$ & 8 & $\begin{array}{c}0.4 \\
9\end{array}$ & 24 & $\begin{array}{c}0.4 \\
9\end{array}$ & 26 & 0.54 & 26 \\
\hline $\begin{array}{l}\text { Delay in releasing lands } \\
\text { and solving conflicts }\end{array}$ & $\begin{array}{c}0.5 \\
8\end{array}$ & 26 & $\begin{array}{c}0.4 \\
8\end{array}$ & 27 & $\begin{array}{c}0.4 \\
3\end{array}$ & 29 & $\begin{array}{c}0.5 \\
1\end{array}$ & 23 & 0.50 & 29 \\
\hline $\begin{array}{l}\text { Existence of multiple } \\
\text { rules and decision } \\
\text { makers }\end{array}$ & $\begin{array}{c}0.6 \\
1\end{array}$ & 22 & $\begin{array}{c}0.7 \\
9\end{array}$ & 30 & $\begin{array}{c}0.5 \\
7\end{array}$ & 14 & $\begin{array}{c}0.6 \\
6\end{array}$ & 15 & 0.65 & 12 \\
\hline $\begin{array}{l}\text { Contract conflicts } \\
\text { between the employer } \\
\text { and the investor }\end{array}$ & $\begin{array}{c}0.6 \\
6\end{array}$ & 16 & $\begin{array}{c}0.7 \\
7\end{array}$ & 3 & $\begin{array}{c}0.5 \\
7\end{array}$ & 15 & $\begin{array}{c}0.5 \\
6\end{array}$ & 21 & 0.64 & 15 \\
\hline
\end{tabular}




\begin{tabular}{|l|c|c|c|c|c|c|c|c|c|c|}
\hline $\begin{array}{l}\text { Disadvantageous } \\
\text { bureaucracies }\end{array}$ & $\begin{array}{c}0.7 \\
9\end{array}$ & 3 & 0.8 & 6 & 0.6 & 5 & 0.6 & 9 & 0.74 & 3 \\
\end{tabular}

\subsection{Analyzing the items}

Based on the rankings provided in table5, the five effective factors of delay in the construction of port operational areas from the employers' point of view are: 1.Investor's reduced financial capacity for providing the right cash flow (RII=0.85); 2.Increased material and equipment costs (RII=0.79); 3. Disadvantageous bureaucracies (RII=0.79); 4. Contractor's financial problems $(\mathrm{RII}=0.78)$; and 5.Delay in providing cash flow and payment to personnel and subcontractors $(\mathrm{RII}=0.75)$.

Based on the rankings provided in table 5, the five effective factors of delay in the construction of port operational areas from the investors' point of view are: 1.Increased material and equipment costs (RII=0.82);2. Disadvantageous bureaucracies (RII=0.80);3. Existence of multiple rules and decision makers (RII=0.79); 4. Delay in decision making (RII=0.78); (5) Delay in project approval and notification (RII=0.77).

Based on the rankings provided in table 5, the five effective factors of delay in the construction of port operational areas from the consultants' point of view are: 1.Degree of monitoring and guiding the contractors(RII=0.66); 2.Investor's reduced financial capacity for providing the right cash flow $(\mathrm{RII}=0.66) ; 3$. Deficient planning and time scheduling $(\mathrm{RII}=0.65)$; 4. Contractor's financial problems $(\mathrm{RII}=0.65)$; 5. Disadvantageous bureaucracies $(\mathrm{RII}=0.65)$.

Based on the rankings provided in table 5, the five effective factors of delay in the construction of port operational areas from the contractors' point of view are: 1.Increased material and equipment $\operatorname{costs}(\mathrm{RII}=0.83)$; 2.Investor's reduced financial capacity for providing the right cash flow (RII=0.78);3. Contractor's financial problems ( $\mathrm{RII}=0.77)$; 4.Delay in invoice approval and payment $(\mathrm{RII}=0.74)$; 5.Delay in providing cash flow and payment to personnel and subcontractors $(\mathrm{RII}=0.72)$.

It can therefore be concluded that all three groups of employers, investors and consultants believe that disadvantageous bureaucracies comprise a major factor for delay. The financial 
problems of the investors (providing cash flow, delay in making payments and reduced financial capacity) comprise another very common and important factor for delay in the construction of port operational areas according to the groups of employers, consultants and contractors. Besides the disadvantageous bureaucracies and increased material and equipment costs, which are among the 10 main factors of delay according to all four groups of project partners, it appears that the employers take the investors' financial problems as the most effective factor for delay (in general, the investors'limited financial capacity challenges the conclusion of the project if loaning from the bank is not possible or if the costs of construction rise). Mean while, the investors take the employers' delay in making decisions or approving the project as the major factor for delay (given the official rules, time-consuming official processes and the many regulatory institutions, administrative works take very long to come to a conclusion). Table 5 presents rankings of the study's assumptions based on the relative importance index.

\subsection{Analysis of assumptions (estimating the model coefficients)}

Table 7 presents the variable coefficients and the student's t-test values yielded by the structural model. According to results obtained by the PLS method, the absolute value for the student's t-test is higher than 1.96 for all variables of the model,and the assumptions of the study are therefore confirmed.

Table 7. Variable coefficients and the student's t-test results yielded by the structural model

\begin{tabular}{|c|c|c|c|c|c|}
\hline \multicolumn{6}{|c|}{ Structural Model--Bootstrap } \\
\hline & $\begin{array}{c}\text { Entire } \\
\text { Sample } \\
\text { estimate }\end{array}$ & $\begin{array}{c}\text { Mean } \\
\text { of } \\
\text { Subsamples }\end{array}$ & $\begin{array}{c}\text { Standard } \\
\text { error }\end{array}$ & T-Statistic & Conclusion \\
\hline monitoring->Delay & 0.1110 & 0.1104 & 0.0179 & 6.2035 & $\begin{array}{l}\text { Inadequate } \\
\text { monitoring is } 0.11 \\
\text { effective on delays } \\
\text { in the construction }\end{array}$ \\
\hline
\end{tabular}




\begin{tabular}{|c|c|c|c|c|c|}
\hline & & & & & $\begin{array}{l}\text { and operation of } \\
\text { port operational } \\
\text { areas }\end{array}$ \\
\hline poor->Delay & 0.1970 & 0.1949 & 0.0160 & 12.3199 & $\begin{array}{l}\text { Poor planning and } \\
\text { time scheduling is } \\
0.19 \text { effective on } \\
\text { delays in the } \\
\text { construction and } \\
\text { operation of port } \\
\text { operational areas }\end{array}$ \\
\hline Improper->Delay & 0.2360 & 0.2371 & 0.0167 & 14.1645 & $\begin{array}{l}\text { Improper allocation } \\
\text { of resources is } 0.24 \\
\text { effective on delays } \\
\text { in the construction } \\
\text { and operation of } \\
\text { port operational } \\
\text { areas }\end{array}$ \\
\hline Other->Delay & 0.2790 & 0.2784 & 0.0213 & 13.0791 & $\begin{array}{l}\text { Cash flow changes } \\
\text { are } 0.28 \text { effective } \\
\text { on delays in the } \\
\text { construction and } \\
\text { operation of port } \\
\text { operational areas }\end{array}$ \\
\hline Fund->Delay & 0.1610 & 0.1625 & 0.0172 & 9.3639 & $\begin{array}{l}\text { Failure to fund the } \\
\text { projects on time is } \\
0.16 \text { effective on } \\
\text { delays in the } \\
\text { construction and } \\
\text { operation of port }\end{array}$ \\
\hline
\end{tabular}


operational areas

\begin{tabular}{|c|c|c|c|c|c|}
\hline Cash flow->Delay & 0.2780 & 0.2810 & 0.0225 & 12.3648 & $\begin{array}{l}\text { Other factors are } \\
0.27 \text { effective on } \\
\text { delays in the } \\
\text { construction and } \\
\text { operation of port } \\
\text { operational areas }\end{array}$ \\
\hline
\end{tabular}

\subsection{Pair wise Correlation Analysis}

The pair wise correlation coefficient is used to clarify the correlation between the delay factors. Table 8 presents the results:

Table 8. Pair wise Correlation Analysis

\begin{tabular}{|c|c|c|c|c|c|c|}
\hline \multicolumn{7}{|c|}{ Correlation of Latent Variables } \\
\hline & Monitoring & Poor & Improper & Delay & Other & Funding \\
\hline Poor & 0.597 & & & & & \\
\hline Improper & 0.501 & 0.539 & & & & \\
\hline Delay & 0.657 & 0.801 & 0.785 & & & \\
\hline Other & 0.502 & 0.570 & 0.614 & 0.868 & & \\
\hline Funding & 0.341 & 0.419 & 0.424 & 0.728 & 0.787 & \\
\hline Cash flow & 0.415 & 0.664 & 0.530 & 0.802 & 0.535 & 0.455 \\
\hline
\end{tabular}

As evident in table 8, poor planning and time scheduling has a significant positive relationship (0.597) with inadequate monitoring .Moreover, the improper allocation of resources has a significant positive relationship (0.539) with poor planning and time scheduling. Cash flow changes also have a significant positive relationship (0.455)with the failure to provide funding on time. 


\section{RESULT \& DISCUSSION}

The present research aimed to identify factors of delay and their relationship with delays in the construction of port operational areas in Iran (Shahid Rajaee Port Complex); to this end, it developed assumptions based on the available literature around the topic. Applying the statistical hypothesis testing and the student's t-test for calculation, the assumptions were either confirmed or rejected. Moreover, the main factors of delay in the construction of port operational areas were identified based on the relative importance index and were then ranked according to the four groups involved in the project.

- Increased material and equipment costs $(\mathrm{RII}=0.77)$

According to studies conducted on delay factors in concluding projects of the construction industry by Faridi and El-Sayegh (2006) in the UAE and by Sambasivan and Soon (2007) in Malaysia,the gradual increase in material and equipment costs was a major factor for delay.

- Investor's reduced financial capacity for providing the right cash flow (RII=0.75)

This factor could be the result of increasing energy costs in the national or international markets or the increasing labor wages without any change to warehousing, transit and transshipment tariffs due to the strong competition between ports in the region. In a study conducted on construction projects of the public sector in Saudi Arabia, Al-Kharashi and Skitmore (2009) found financial problems to be a major factor for delay.

- Disadvantageous bureaucracies(RII=0.74)

Assaf et al found that bureaucracies existing in organizations comprise a major factor for delay in massive construction projects. Studies conducted on delay factors in concluding construction projects by Iyer and Jha (2006) in India and by Marzouk and El-Rases (2013) in Egypt also found these bureaucracies to be a major factor for delay.

- Contractor's financial problems (RII=0.73)

Again, studies conducted on delay factors in concluding industrial construction projects by Faridi and El-Sayegh (2006) in the UAE, by Sambasivan and Soon (2007) in Malaysia, and by Marzouk and El-Rases (2013)in Egypt, found that contractor's financial problems comprise a major factor for delay.

- Delay in decision making $(\mathrm{RII}=0.71)$ 
Delay in decision-making was also identified as an important delay factor in the construction of port operational areas due to the nature of public sector projects and the need for reporting to several regulatory organizations. Studies conducted on the untimely conclusion of construction projects by El-Razek et al (2008) in Egypt, by Odeh and Battaineh (2002) on conventional contracts in developing countries, by Lo et al(2006) in Hong-Kong and by Aibinu and Odeyinka (2006) in Nigeria, all found delay in decision making by the employer to be a major factor for delay.

\section{CONCLUSION}

Developing infrastructures and operational areas is a serious matter in ports. The present research aimed to identify factors of delay in the construction of port operational areas and therefore defined 6 assumptions (inadequate monitoring, poor planning and time scheduling, improper allocation of resources, cash flow changes, failure to fund the projects on time and other factors) and then developed a 30-item questionnaire distributed it among project partners. At the end, the main factors for delay were identified according to the relative importance index, that is, increased material and equipment costs, investor's reduced financial capacity for providing the right cash flow, disadvantageous bureaucracies, contractor's financial problems and delay in decision making.

Based on results of study, it was found that inadequate monitoring has significant and positive impact on delay in construction and operation of operating area. The results of analysis of this hypothesis are consistent with results of Faridi et al. (2006), Doli, et al (2011) and Oranghi et al (2011).

Poor planning and time scheduling have significant and positive impact on the delay in construction of the port operational area. Results of this hypothesis are in line with results of El Mamani et al. (2011), Kushki et al. (2005), Asif and Alhaji. (2005) and Dooley (2011). Improper allocation of resources has significant and positive impact on delay in construction and operation of port area. The results of this study are consistent with the results of Lu et al. (2008), Oranghi et al (2011), and Fallahnejad (2013). 
A cash flow change has significant and positive impact on delay in construction and operation. The results of this hypothesis are in line with the results of Alkhalil et al (1999), Asif et al (1995), and Lu et al (2008).

Failure to fund projects on time has positive impact on delay in construction and operation of operating area. This result is consistent with results of Fallahnejad et al (2012) and Lu et al (2008).

Other factors (political, social, economic and climate, etc.) have significant and positive impact on the delay in the construction and operation of operational area of port. These results are consistent with results of Alkhalil et al (1999) and Yang et al (2009).

\section{RECOMMENDATIONS AND STRATEGIES FOR REDUCING DELAY FACTORS}

Based on results of the study with regard to the main factors identified for delay and according to the four groups involved in concluding projects, the following solutions are recommended:

Formation of a cost management department (for planning resources, cost-estimation, predicting cost changes and cost budgeting);employing a value engineering team; reinforcing cost engineering; forming close relationships between the cost estimation unit and the executive units; developing an efficient cost-time control system; purchasing on credit; taking short-term loans ; using electronic and office automation systems; using the one window system; using shared accounts; timely payments to the contractor; making payments on account in order to financially strengthen the contractor; making final decisions based on the time schedule; regular participation of decision makers in meetings; and devising an assessment and promotional system for the employers' agents involved in the project.

\section{REFERENCES}

[1] Aibinu, A.A., Odeyinka, H.A. Construction delays and their causative factors in Nigeria. Journal of Construction Engineering Management. 2006, 132, 667-677.

[2] Al-Kharashi, A., Skitmore, M. Causes of delays in Saudi Arabian public sector construction projects. Construction Management and Economics, 2009, 27, 3-23. 
[3] Al-Khalil, M. I., Al-Ghafly, M. A. Delay in public utility projects in Saudi Arabia. International Journal of Project Management, 1999, 17(2), 101-106.

[4] Al-Momani, A. H. Construction delay: a quantitative analysis. International Journal of Project Management, 2000, 18, 51-59.

[5] Assaf, Sadi A., Hejji, Sadiq Al. Causes of delay in large construction projects. International Journal of Project Management, 2006, 24(4), 349-357.

[6] Assaf, S.A., Al-Khalil, M., Al-Hamzi, M. Causes of delays in large building construction projects. ASCE Journal of Management in Engineering, 1995, 11, 45-50.

[7] Chan DWM, Kumaraswamy MM. A comparative study of causes of time overrun in Hong kong construction projects. Int J Project Manager 1997, 15(1), 55-63.

[8] Doloi H., Sawhney A., Iyer K.C.,Rentala S. Analyzing factors affecting delays in Indian construction projects. International Journal of project management, 2012, 30(4), 479-489.

[9] El-Razek, A.M.E., Bassioni, H.A., Mobarak, A.M. Causes of delay in building construction projects in Egypt. Journal of Construction Engineering Management, 2008, 134, 831-841.

[10] Fallahnejad, M.H. Delay causes in Iran gas pipeline projects. International Journal of project management, 2013, 31(1), 136-146.

[11] Faridi AS, El-Sayegh SM. Significant factors causing delay in the UAE construction industry. Construction Management Economics;. 2006, 24(11), 1167-76.

[12] Hassan Zadeh Mohammadi, M. L. Maritime transport economics, Aramesh Publisher,Tehran, 2011, 214, 240- 307.

[13] Iyer, K.C., Jha, K.N. Factors affecting cost performance: evidence from Indian construction projects. International Journal of Project Management , 2005, 23, 283-295.

[14] Koushki PA, Al-Rashid K, kartam N. Delays and cost increases in construction of private residential projects in Kuwait. Constr Manage Econ 2005, 23(3), 285-94.

[15] Kumaraswamy MM, Chan DWM. Contributors to construction delays. J Constr Manage Econ, 1998, 16(1), 17-29.

[16] Lo TY, Fung IWH, Tung KCF. Construction delay in Hong Kong civil engineering project. J Constr Eng Manage, ASCE, 2006, 132(6), 636-49. 
[17] Luu, V.T., KIM, S.Y., Tuan, N.V., Ogunlana, S.O., Quantify schedule risk in construction projects using Bayesian belief networks, 2009, 27, 39-50.

[18] Mansfield NR, Ugwu OO, Doran T. Causes of delay and cost overruns in Nigerian construction projects. Int J Project Manager, 1994, 12(4), 254-60.

[19] Marzouk, M.M., EL-Rasas, T.I.”Analyzing delay causes in Egyptian construction projects”. Procedia Engineering , January 2013

[20] Mezher, T., Tawil W. Causes of delays in the construction industry in Lebanon. Eng constr Arch Manage J, 1998, 5(3), 252-60.

[21] Odeh, A.M., Battaine, H.T.,. Causes of construction delay: traditional contracts. International Journal of Project Management, 2002, 20, 67-73.

[22] Odeyinka, H.A., Yusif, A.The causes and effects of construction delays on completion cost of housing projects in Nigeria. Journal of Financial Management of property and Construction, 1997, 2, 31-44.

[23] Orangi A., Palaneeswaran E., Wilson J. Exploring delay in Victoria-Based Australian Pipeline project. The twelfth East Asia-pacific conference on structural Engineering and construction, volume 14,issue, 2011, 874-881.

[24] Parsa, A.M., Famouri, S.S., Evaluating the techniques of delay effective technique, Sixth International Project Management Conference, Iran, Tehran, 2011.

[25] Sambasivan, M. and Soon, Y. W., "Causes and effects of delays in Malaysian construction Industry”, International Journal of Project Management, 2007, 25, 517- 526.

[26] Soskia, Walters, Ports Marketing, Translated by Sorayya Qeisari and Hamid Hamidi, Tehran: Asrar-e Danesh

[27] Sweis, G., Sweis, R., Abu Hammad A. , Shboul, A. Delays in construction projects, The case of Jordan International journal of project management, 2008, 26 (6), 665-674.

[28] Williams, T., Assessing Extension of Time delays on major projects. International Journal of Project Management, 2003, 21, 19.

[29] Team of Authors, (2005), The Regional and Global Role of Iranian Ports in Coming 10 Years, Tehran, Iranian Ports and maritime Organization. 
[30] Yang J.B., Yang C.C., Kao C.K. "Evaluating schedule delay causes for private participating public construction works under the Build-Operate-Transfer model". International Journal of project management, 2010, 28, 569-579.

\section{How to cite this article:}

Shirowzhan M, Shanaki M, Hasan Sebt M, Naghash Toosi H. Evaluating delay factors in the construction and operation of port operational areas (case study: shahid rajaee port complex). J. Fundam. Appl. Sci., 2016, 8(2S), 732-763. 